\title{
The Oil and Gas Basins of Africa
}

\author{
R. C. Selley ${ }^{1}$ and D. van der Spuy ${ }^{2}$ \\ ${ }^{1}$ Imperial College, London.E-mail: r.selley@imperial.ac.uk \\ ${ }^{2}$ Petroleum Agency, SA. E-mail: vanderspd@petroleumagencysa.com
}

DOI: 10.18814/epiiugs/2016/v39i2/95786

Today Africa produces about 7.0\% of the world's oil and a similar amount of the world's gas from a range of basins that include intra-cratonic sags, epicratonic embayments and basins that form part of the rift-drift sequence caused by the post-Triassic break up of Pangaea. Petroleum occurs throughout the stratigraphic column from Late Archaean to Recent. There is no doubt that, given political stability, African petroleum production could be dramatically enhanced with little further exploration. There is still great potential for future oil and gas discoveries, especially offshore, as seismic, drilling and production technology constantly improve.

There is also potential for producing unconventional petroleum resources, both coal-bed methane from Karoo coals, and shale gas production in the Karoo basin and in North African source rocks of Algeria and Libya in particular.

\section{Introduction}

Africa has a history of petroleum production stretching back at least some 2,500 years since oil was produced from natural seepages in Tunisia (Herodotus, 450 BC). In 2013 Africa held $7.7 \%$ of the world's oil reserves and $7.6 \%$ of the world's gas reserves (Table 1).

Table 1. Africa's oil and gas reserves in 2013. From BP Energy Review, June 2014. $* \geq 100$ years. $\mathbf{R} / \mathbf{P}=$ Resources to production ratio

\begin{tabular}{|c|c|c|c|c|c|c|}
\hline \multirow[t]{2}{*}{ Country } & \multicolumn{3}{|c|}{ OIL } & \multicolumn{3}{|c|}{ GAS } \\
\hline & $\mathrm{BBL}$ & $\begin{array}{l}\% \text { of } \\
\text { Total }\end{array}$ & $\begin{array}{l}\mathrm{R} / \mathrm{P} \\
\text { Ratio }\end{array}$ & TCF & $\begin{array}{l}\% \text { of } \\
\text { Total }\end{array}$ & $\begin{array}{r}\mathrm{R} / \mathrm{P} \\
\text { Ratio }\end{array}$ \\
\hline Algeria & 12.2 & $0.7 \%$ & 21.2 & 159.1 & 2.4 & 57.3 \\
\hline Angola & 12.7 & $0.8 \%$ & 19.3 & & & \\
\hline Chad & 1.5 & $0.1 \%$ & 43.5 & & & \\
\hline $\begin{array}{l}\text { Republic of Congo } \\
\text { (Brazzaville) }\end{array}$ & 1.6 & $0.1 \%$ & 15.6 & & & \\
\hline Egypt & 3.9 & $0.2 \%$ & 15.0 & 65.2 & 1 & 32.9 \\
\hline Equatorial Guinea & 1.7 & $0.1 \%$ & 15.0 & & & \\
\hline Gabon & 2.0 & $0.1 \%$ & 23.1 & & & \\
\hline Libya & 48.5 & $2.9 \%$ & $*$ & 54.7 & 0.8 & $*$ \\
\hline Nigeria & 37.1 & $2.2 \%$ & 43.8 & 179.4 & 2.7 & * \\
\hline South Sudan & 3.5 & $0.2 \%$ & 96.9 & & & \\
\hline Sudan & 1.5 & $0.1 \%$ & 33.7 & & & \\
\hline Tunisia & 0.4 & $<0.05$ & 18.7 & & & \\
\hline Other African countries & 3.7 & $0.2 \%$ & 47.7 & 43.3 & 0.7 & 56.9 \\
\hline Total & 130.3 & $7.7 \%$ & 40.5 & 502 & 7.6 & 69.5 \\
\hline
\end{tabular}

Essentially the African continent is a complex craton of largely Pre-Cambrian continental crust. On this are superimposed sedimentary basins of diverse age and tectonic style (Figure 1). These basins can be broadly grouped into several types: the intra-cratonic Palaeozoic basins, such as those of North Africa, the Zaire Basin of the DRC and Congo, and the Karoo of Southern Africa as well as the saline riftdrift suite of basins of the predominantly east and west African coastal margins, the intra-cratonic rift basins of central Africa, and the TertiaryRecent delta cones of the Niger and Nile rivers. Petroleum is found throughout the stratigraphic column extending from geographically widespread seepages in Recent sediments to oil in fluid inclusions in the Late Archaean sediments of the Witwatersrand basin (England $e t$ al., 2002).

Given this large and diverse amount of geology, an attempt to write such a concise account of the habitat of African petroleum is an extremely daunting task. Nevertheless, this paper attempts to cover the topic imparting as much information as possible graphically, rather than by means of text. The paper is arranged as an itinerary that begins with the basins of North Africa and follows an anticlockwise pilgrimage of the various basins - ending up with the Nile delta.

\section{North Africa}

North Africa consists of a northerly thickening wedge of largely Palaeozoic sediments, from the Pre-Cambrian massifs, named from west to east: Reguibat, Hoggar, Tibesti and the Arabo-Nubian shield. Geologists from Doughty (1888) to Husseini (1990) onwards, have noted the remarkably uniform stratigraphy of the Palaeozoic, and Lower Palaeozoic rocks in particular, from the Atlantic Ocean in the west, to the Arabian Gulf in the east. Indeed South African geologists finding themselves in the Sahara Desert will recognise familiar rocks, such as the equivalents of the Cambrian Table Mountain Sandstone and the Ordovician glacial Pakhuis diamictite. The northerly thickening wedge of sediments now occupies a suite of cratonic sag basins, some superimposed on Infra-Cambrian to Cambrian rifts. From west to east, in the northern part of West Africa, these are the Tindouf, Reggane, Timimoun, Illizi, Murzuk and Al Kufra basins (Figures 1 and 2). Each basin has a post-Palaeozoic fill of largely continental clastics ranging in age from Triassic to Cretaceous, once colloquially referred to as the 'Nubian Sandstone'. Two main geological provinces disturb this general pattern: the Atlas fold belt of Morocco, Algeria and Tunisia, and the Late Cretaceous to Recent Sirte Basin, or more strictly embayment, of north central Libya.

Desultory petroleum exploration in North Africa throughout the early part of the last century accelerated with the discovery of the giant Hassi Messaoud oil field on a big palaeo-high in the Illizi Basin of Algeria, in 1953. With 10 billion barrels of reserves this is the largest oil field in Africa. The reservoir is the Cambro-Ordovician 


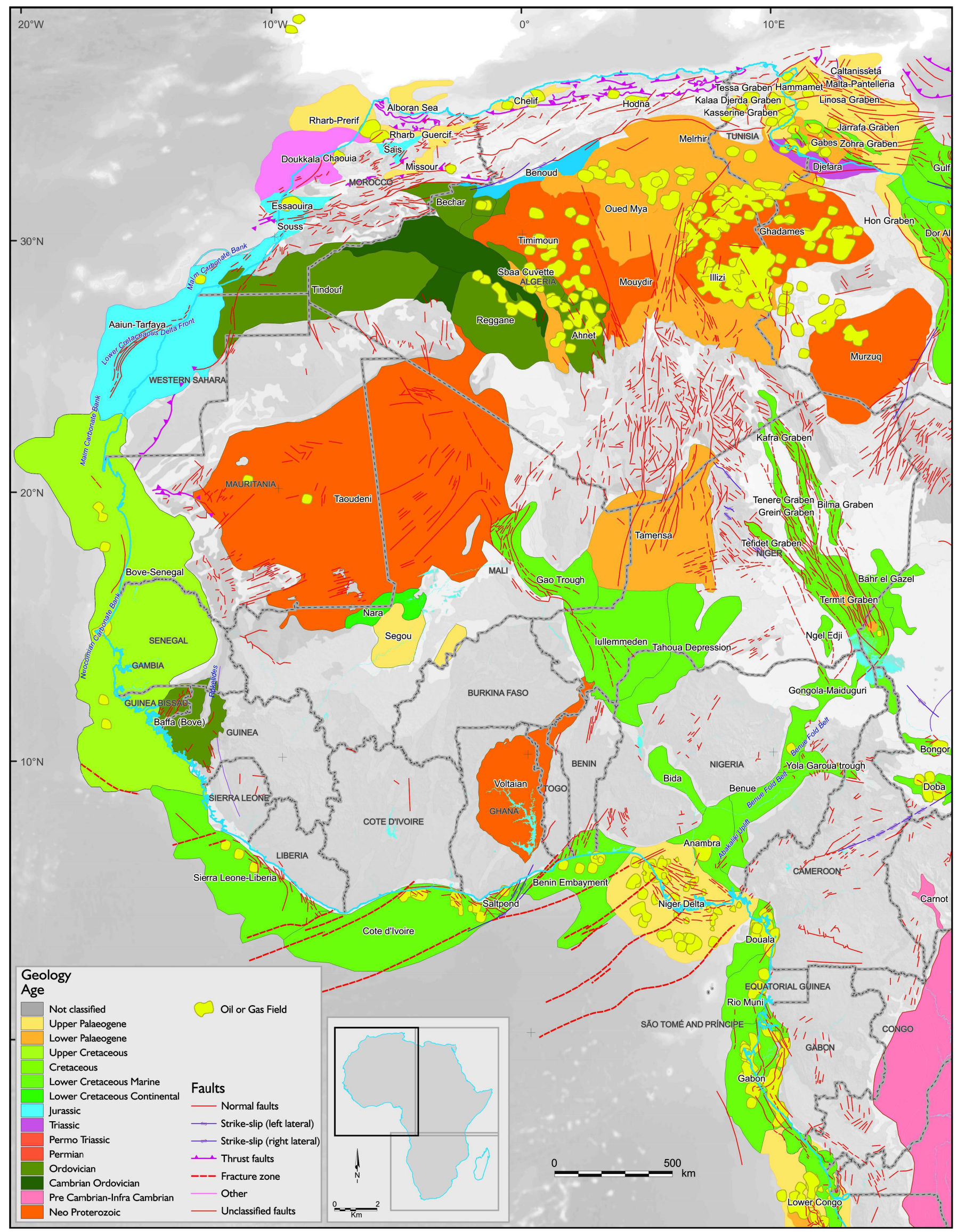

Figure 1a. Map of northwestern Africa showing sedimentary basins \& petroleum plays. Courtesy of the Exploration Framework of Africa Team (․) 


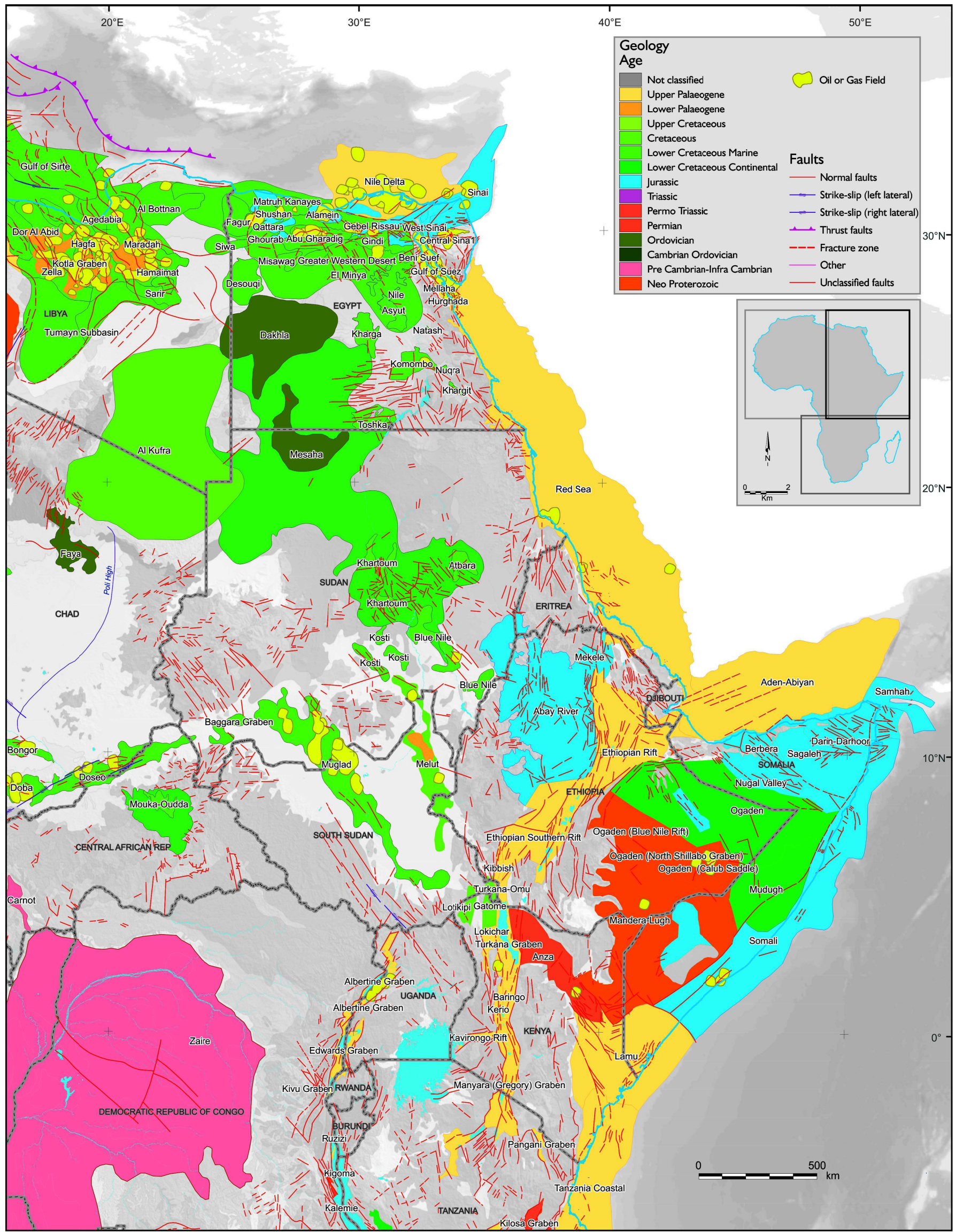

Figure 1b. Map of northeastern Africa showing sedimentary basins \& petroleum plays. Courtesy of the Exploration Framework of Africa Team ${ }^{\circ}$. 


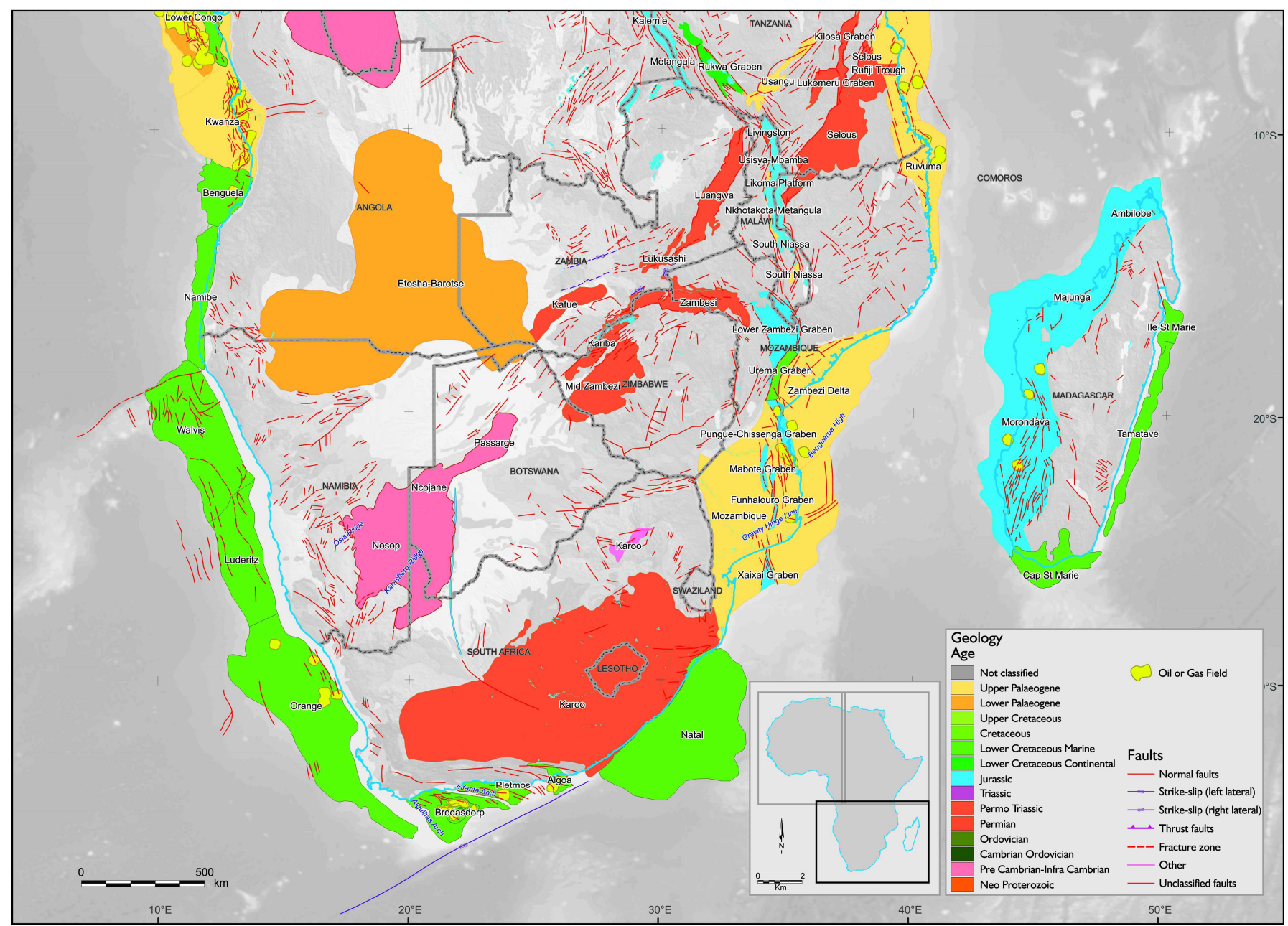

Figure 1c. Map of southern Africa showing sedimentary basins \& petroleum plays. Courtesy of the Exploration Framework of Africa Team ${ }^{\circ}$.

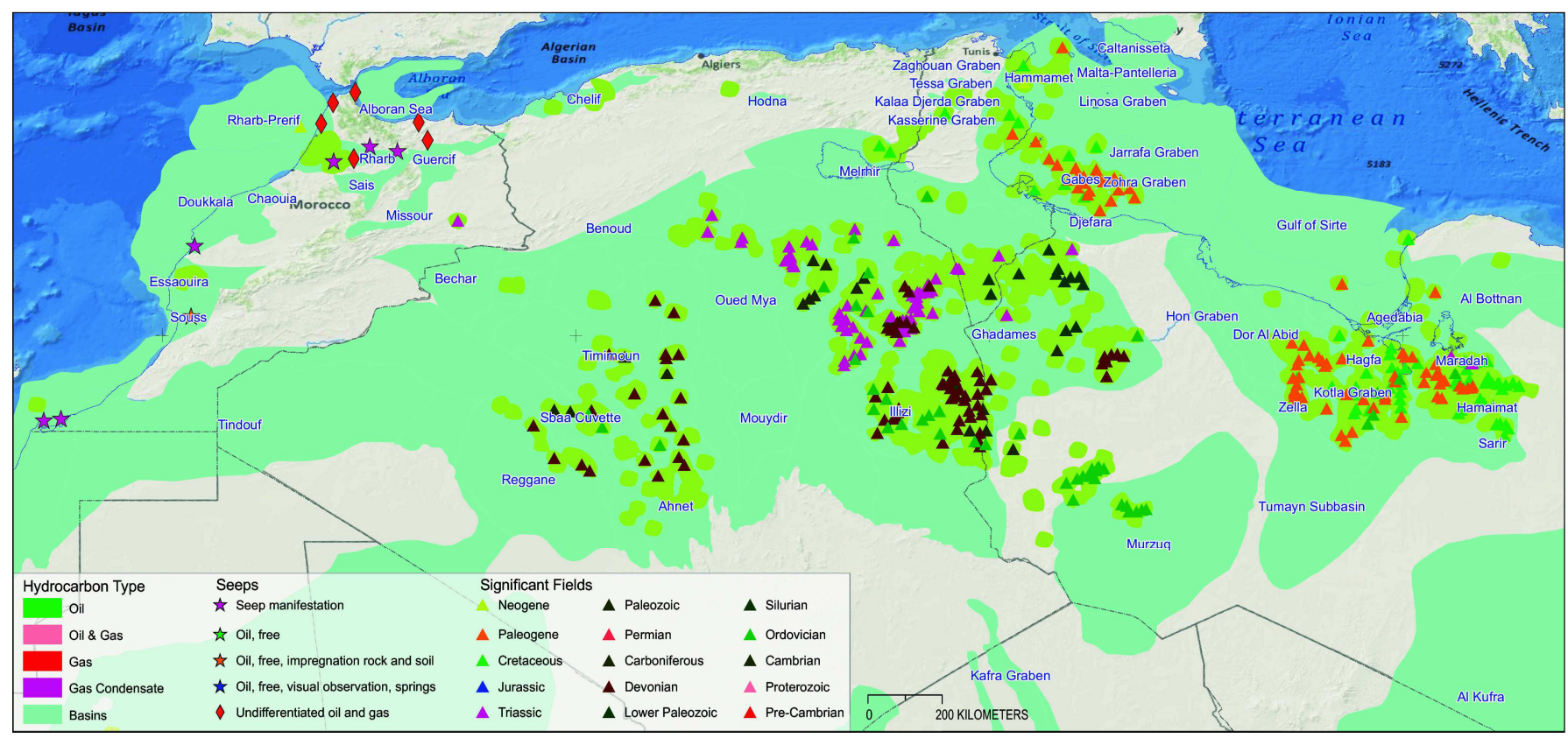

Figure 2. Map showing the main petroleum producing basins of North Africa. Courtesy of the Exploration Framework of Africa Team $@$. 


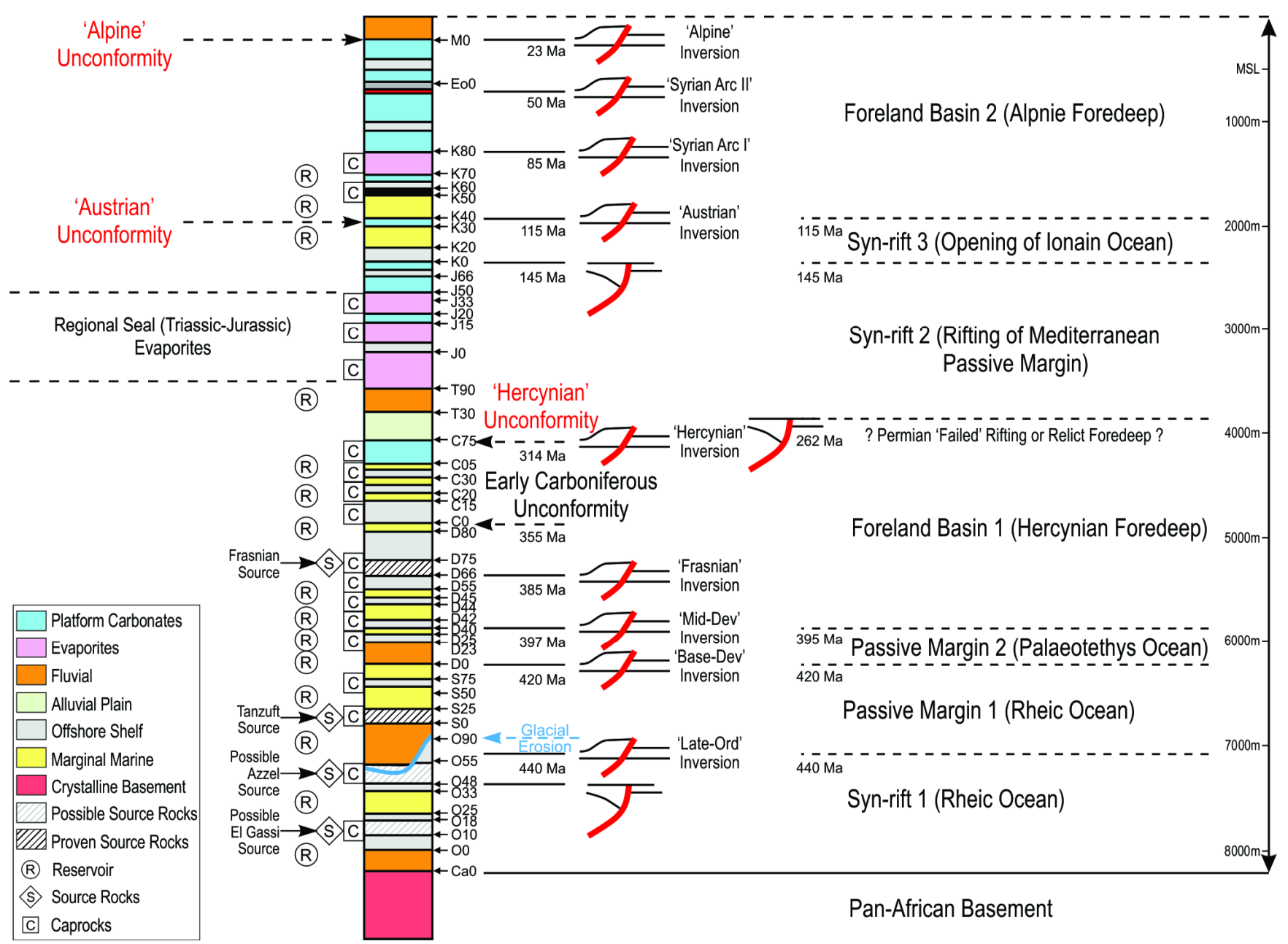

Figure 3. Summary stratigraphic column of North Africa showing the main source and reservoir rocks and tectonic development. From: Dixon et al. (2010).

Hassaouna Sandstone, the source is Silurian Tannezuft shale and the seal comprises Triassic evaporites.

In subsequent years petroleum was found in both older and younger sandstones, with additional source rocks (Figure 3). In Libya the quest for similar fields in the Sirte Basin led to the discovery of late Cretaceous - Lower Eocene carbonate buildups and shoals. These discoveries were followed by the discovery of reservoirs in Early Cretaceous sandstones in the Sarir, Messla and associated fields. There is also potential across all of the North African basins for tight gas production from deeply buried infra-Cambrian and Ordovician source rocks (Craig et al., 2005).

\section{West African Salt Basins}

The concatenation of climate and the gradual break up of Pangaea from north to south led to the formation of evaporites over a series of incipient rift basins along the coast of West Africa, from Morocco to Namibia (Figure 4). The evaporites gradually young north to south, from Permian in the North Sea, Late Triassic-Jurassic along the coast of West Africa, Aptian in Angola and Gabon, and late Jurassic in offshore South Africa. In the West African basins evaporates formed within the rifts. Further south in Gabon and Angola, evaporites postdate the rifting phase and overlie fluvial and lacustrine syn-rift sediments (Figure 5). In Mauritania and Senegal petroleum has been found in salt-related Cretaceous, Palaeogene and Neogene sandstone reservoirs sourced from Jurassic and Late Cretaceous shales (Tari et al., 2003). In Congo, Angola and Gabon, petroleum is trapped in Tertiary submarine fan sands, in Cretaceous carbonate reservoirs associated with complex salt tectonics, and in pre-salt lacustrine carbonates and turbidite sands sourced by inter-fingering non-marine organic-rich shale.

\section{Niger Delta}

The Niger Delta occurs at the southern end of a major series of rifts extending from what is now the Atlantic Ocean to the modern Mediterranean and hosts the largest petroleum province of Africa. These rifts are of Cretaceous age and at one time allowed a continuous seaway to extend across the continent. The Niger Delta consists of three diachronous facies: the on-delta fluvial Benin Formation, delta front sands and muds of the Agbada Formation and the over-pressured slope muds of the Akata Formation. This sediment pile prograded over deep water submarine channel and fan sands (Figure 6). For many years petroleum production came from complex growth-fault, rollover and combination traps above the mobile Akata muds. Improved seismics and the ability to drill in progressively deeper water have extended production into the deep water fan and channel sands (Morgan, 2003). 


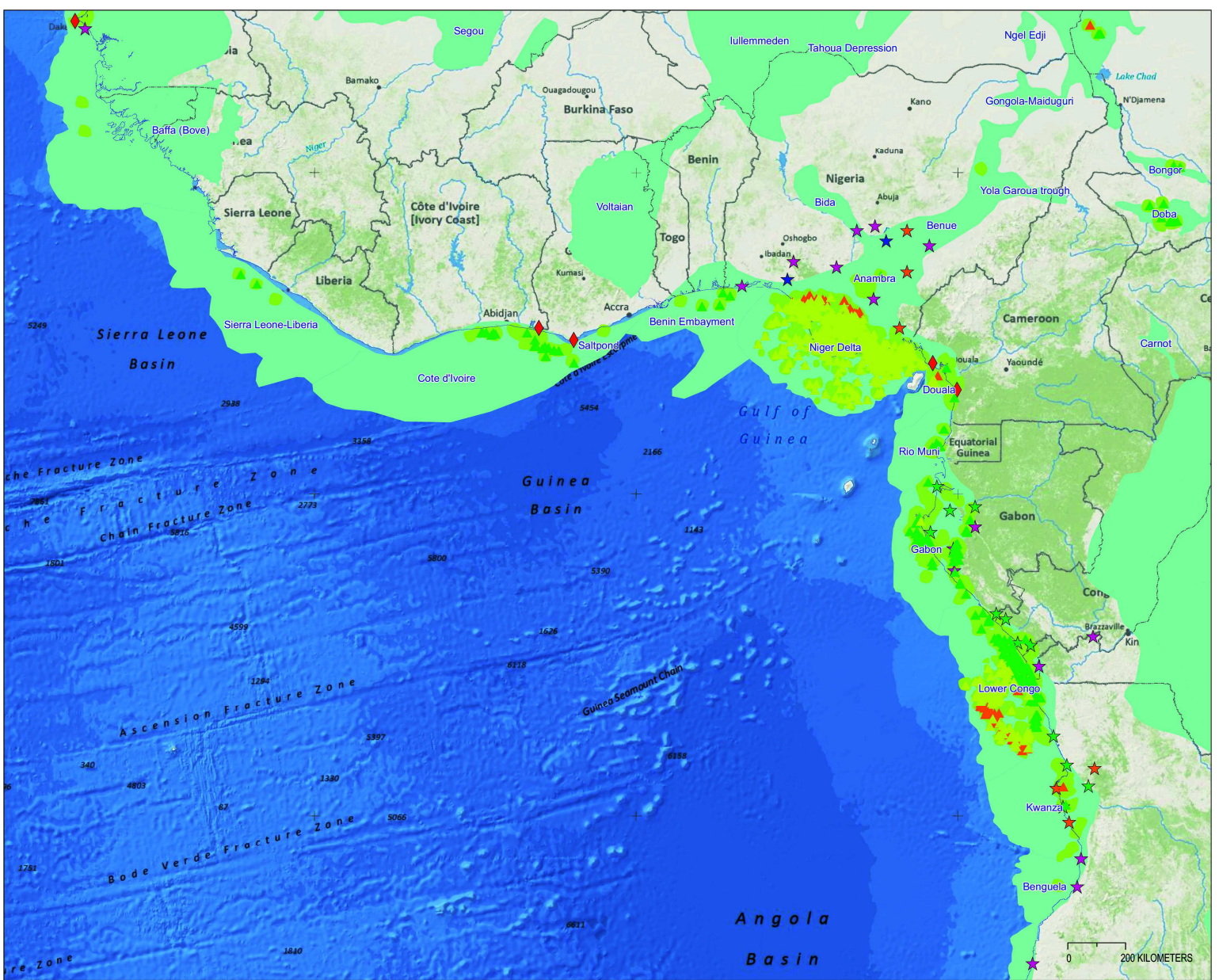

Figure 4. Map showing the petroleum basins of West Africa, including the Niger Delta and the salt basins to the north and south of it. For key see Figure 2. Courtesy of the Exploration Framework of Africa Team $@$.

SYN-RIFT SALT

Morocco, Senegal, The Gambia, Guinea-Bissau, Guinea

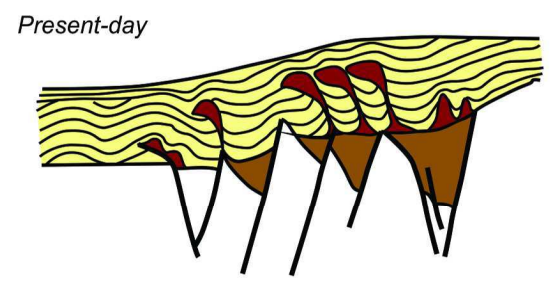

Syn-rift salt deposition

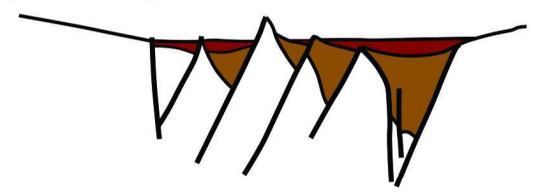

Translation pattern

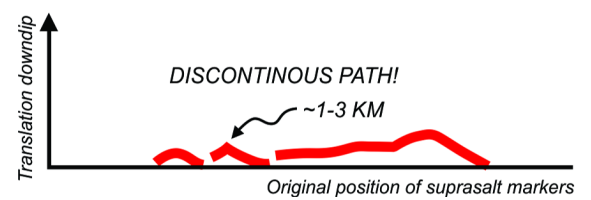

POST-RIFT SALT

Angola, Congo, Gabon,

Equitorial Guinea, Cameroon

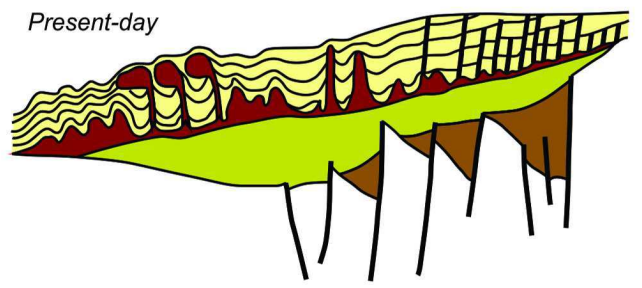

Post-rift salt deposition

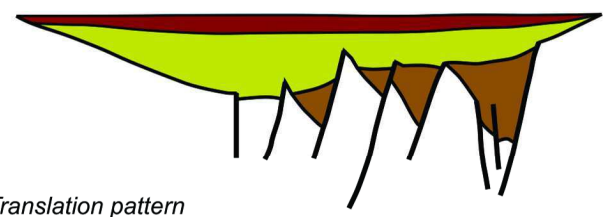

Translation pattern

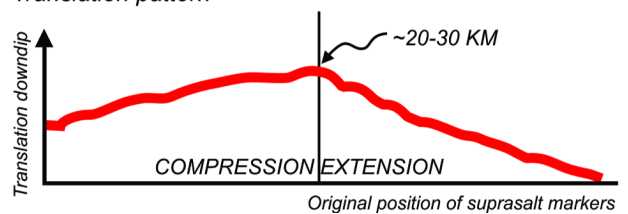

Figure 5. Diagrams showing the evolution of syn-rift salt tectonics in the West African coastal basins north of the Niger Delta (left) and postrift salt tectonics south of the Niger delta. From: Figure Tari et al. (2003). 


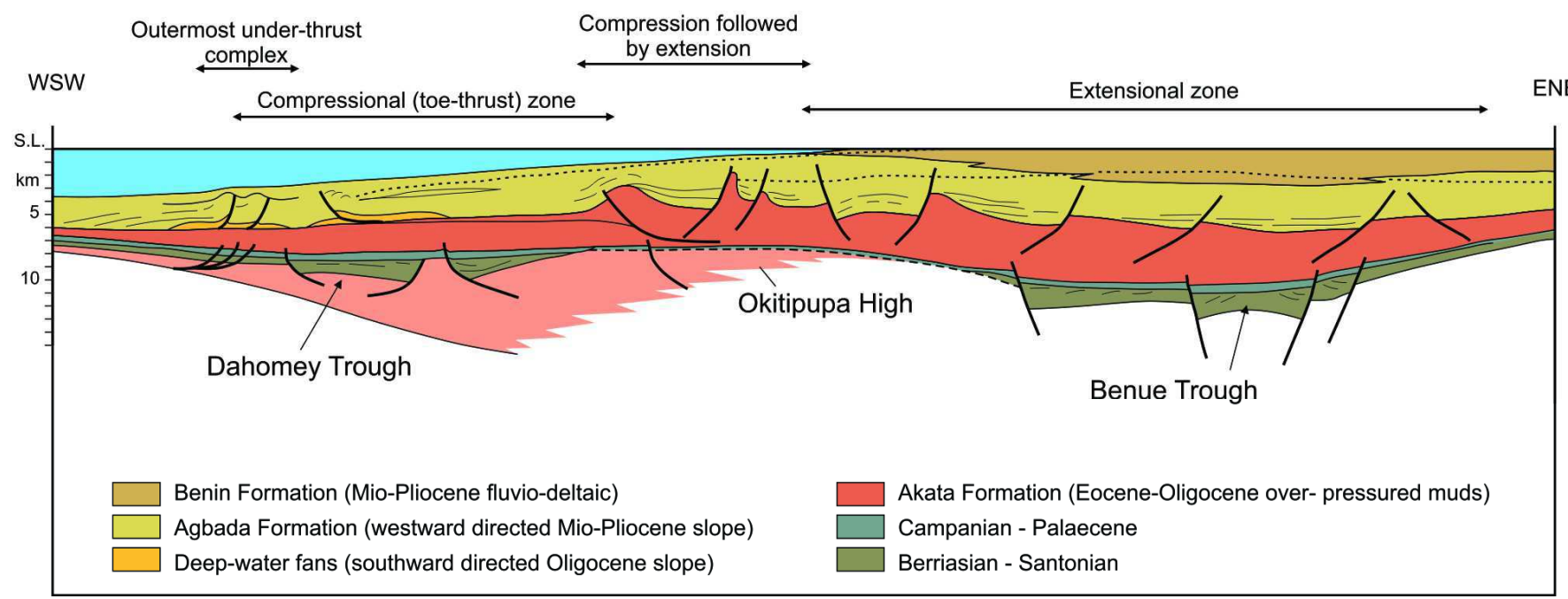

Figure 6. Cross-section through the Niger Delta showing the tri-partite subdivision of the main components of the sediment cone: The fluvio-deltaic Benin Formation, the marine shelf and slope sands and muds of the Agbada Formation, and upwards of $6 \mathrm{~km}$ of marine slope muds of the Akata Formation. Over-pressuring in the Akata Formation has rendered the Akata Formation structurally weak and the entire sediment cone has collapsed on intra-Akata detachment faults creating extensional, fault-diapiric and compressional belts within the apron. From Morgan, (2004).

\section{The rift basins of East Africa}

A series of rifts developed across the African crust later than those that permitted the trans-Saharan seaway. These include the East African rift valleys that are obvious topographic features today (Figure 7), as well as earlier ones sometimes buried beneath sag basins. Petroleum seeps have long been known along the margins of the East African rifts. A well was drilled at Waki in 1938, but it was not economic to produce petroleum from the rift basins until recent times. Now significant reserves have been discovered in Kenya and in Uganda, along the eastern margin of Lake Albert. The sediment column penetrated to date ranges in age from Late Miocene to Recent, but the oldest sediments in the rift basins are unknown and may even include those of the Karoo Group (Figure 8). The Rukwa and Malawi rifts are reactivated Karoo and Cretaceous rifts. There are two types of petroleum trap: fault blocks with sealing faults, and hanging wall 'flower' structures suggesting lateral displacement of the rift margins during subsidence.

\section{The Sud province of North Central Africa}

What may, for convenience, be termed the Sud province of North
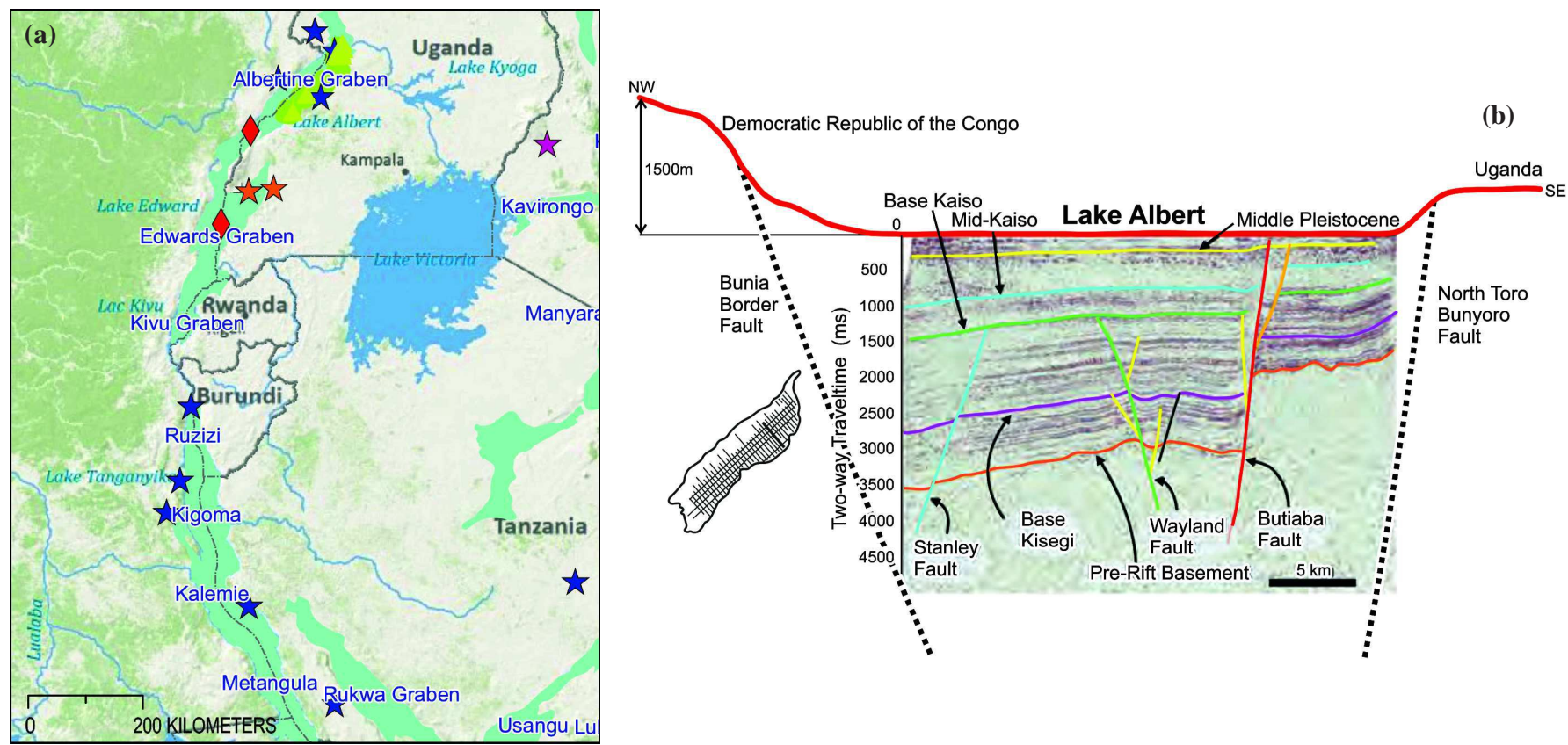

Figure 7. (a) Map of the East African rift basins. For key see figure 2. Courtesy of the Exploration Fabric of Africa Team $@$. (b) Multichannel seismic line 57 from the northern part of Lake Albert (see track line inset for location) From Karp et al. (2012). 
Central Africa, consists of a series of basins extending across Niger, Chad and Sudan (Figures 8, 9 and 10). Unlike the East African rift basins they exhibit little topographic expression and their existence was unknown until gravity surveys, and later seismic surveys, began in the middle of the last century. A desultory petroleum exploration campaign has gone on across these basins for the last 30 years as far as political disturbance allows. Many fields have been discovered, notably the Heglig and Unity fields found in 1982, though these are now depleting. Within the rift structures deep, highly faulted, rift fill sediments of Lower - Upper Cretaceous non-marine sediments, overlain by flat-lying Tertiary to Recent sands and shales that extend beyond the rift boundaries are developed. Lower Cretaceous deep water lacustrine shale provides the source for petroleum in Late Cretaceous fluviodeltaic sands (Guiraud and Bosworth, 1997, Lirong, et al., 2013).

\section{South Africa}

South Africa has four major basins, or rather distinct tectonostratigraphic zones (one onshore and three offshore), that have shown potential for oil and gas (Figure 11). The late Carboniferous to early Jurassic Main or Great Karoo Basin, and its smaller outliers to the north, is the largest and occupies over half of the land surface of the country. The Mesozoic basins that lie almost entirely offshore, originated during the breakup of Gondwana. They are the Orange Basin off the west coast, the Outeniqua Basin off the south coast and the east coast Durban and Zululand Basins.

The onshore Great Karoo Basin is usually described as a retroarc foreland basin that formed on the continental side of the Cape Fold Belt as the Antarctic plate collided with the African plate (e.g.
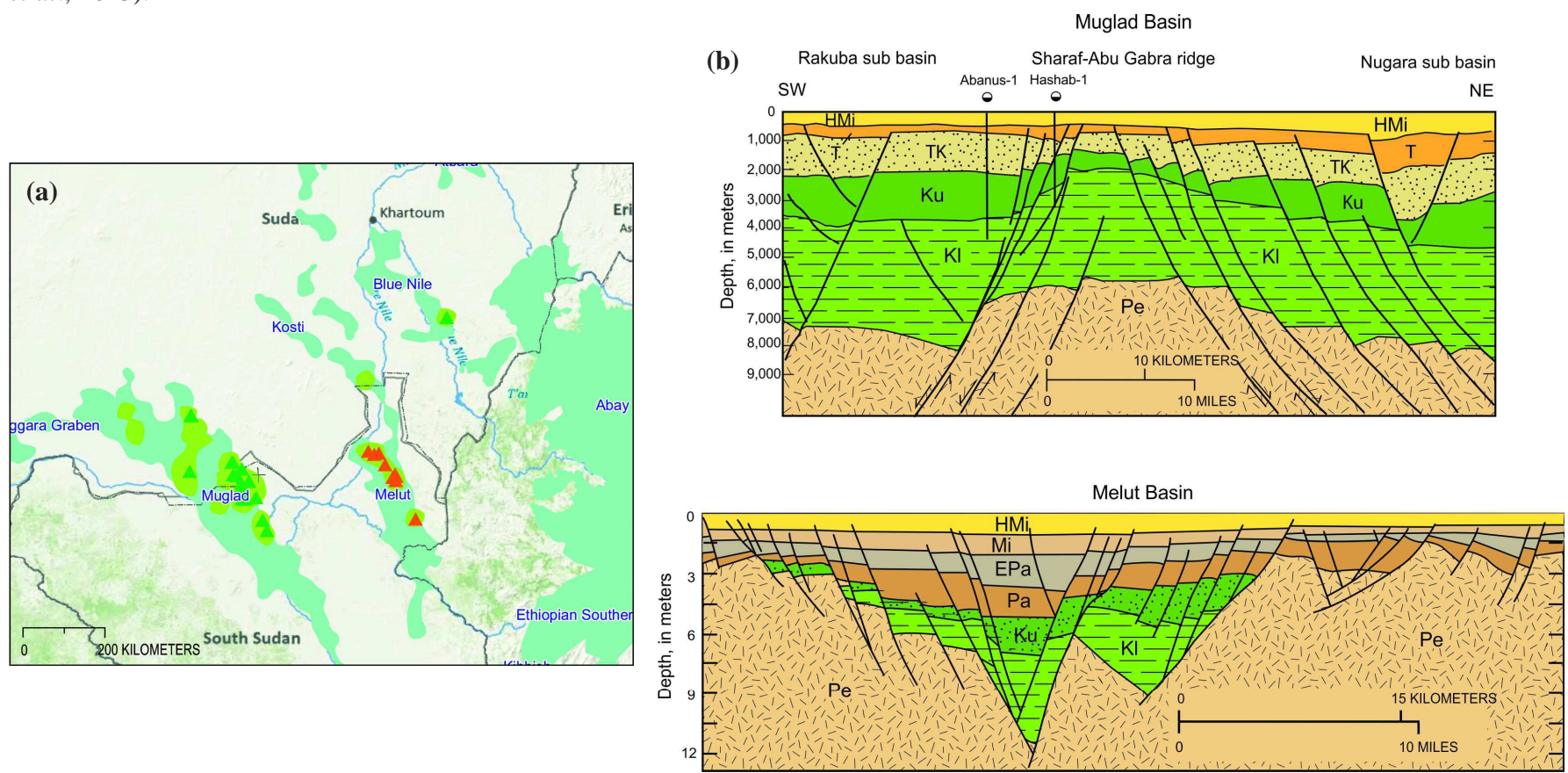

Figure 8. (a) Map of Sudan and adjacent countries showing the location of the Muglad and Melut rift basins. For key see Figure 2. Courtesy of the Exploration Fabric of Africa Team ${ }^{\circ}$. (b) Cross-sections through the Muglad and Melut rift basins. From Brownfield (2010).

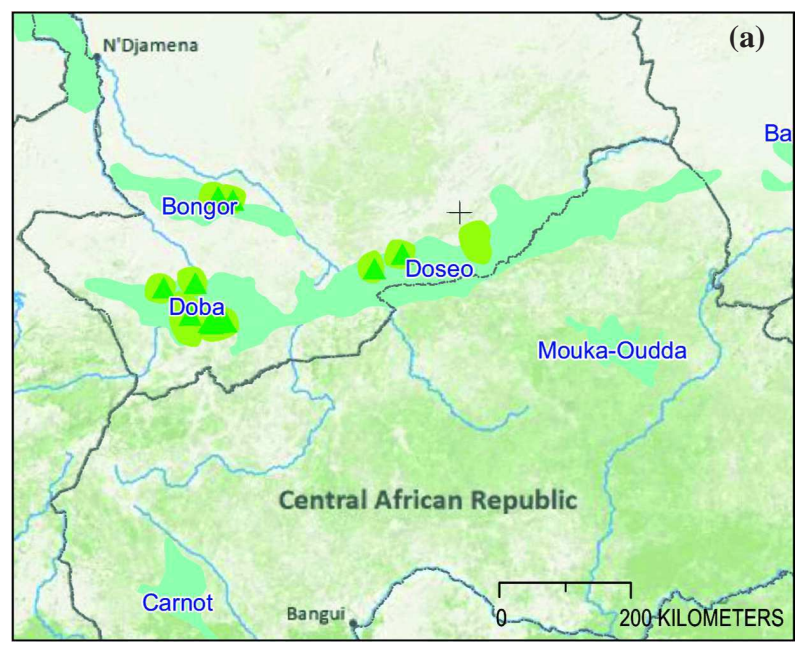

(b)

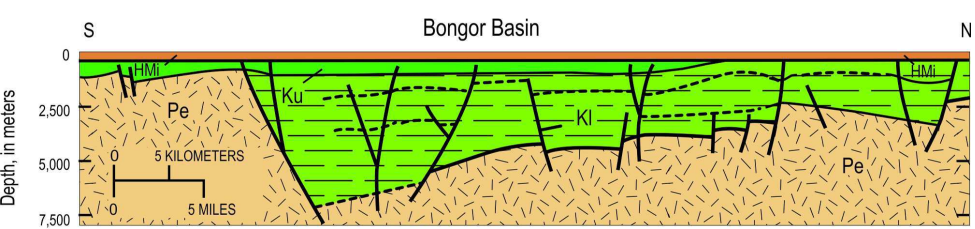
$7,500 \div$

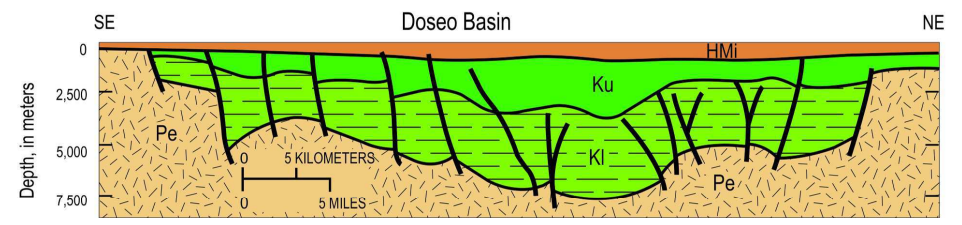

Figure 9. (a) Map of the Bongor and Doseo basins of southern Chad. For key see Figure 2. Courtesy of the Exploration Fabric of Africa Team (‥ (b) Cross-sections of the Bongor and Doseo basins of southern Chad. From Brownfield, (2010). 


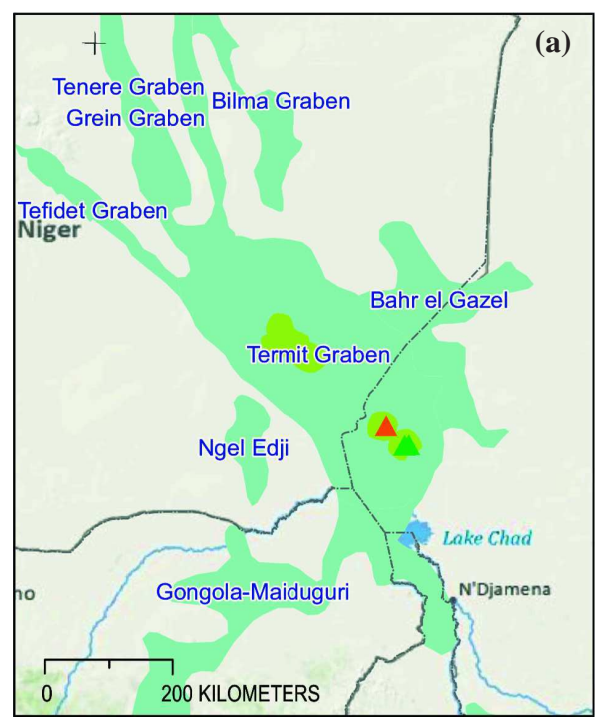

(b)

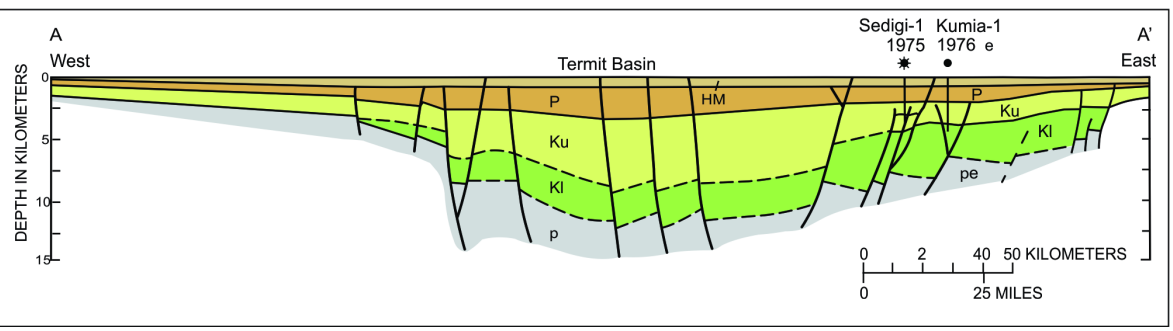

Figure 10. (a) Map of the Termit basin of Niger \& Chad. For key see figure 2. Courtesy of the Exploration Fabric of Africa Team $\bigcirc$. (b) Cross-section of the Termit basin in Niger. Key: pC, Precambrian; Kl, Lower Cretaceous; Ku, Upper Cretaceous; P, Paleogene; HM, Holocene to Miocene. From Brownfield, (2012).

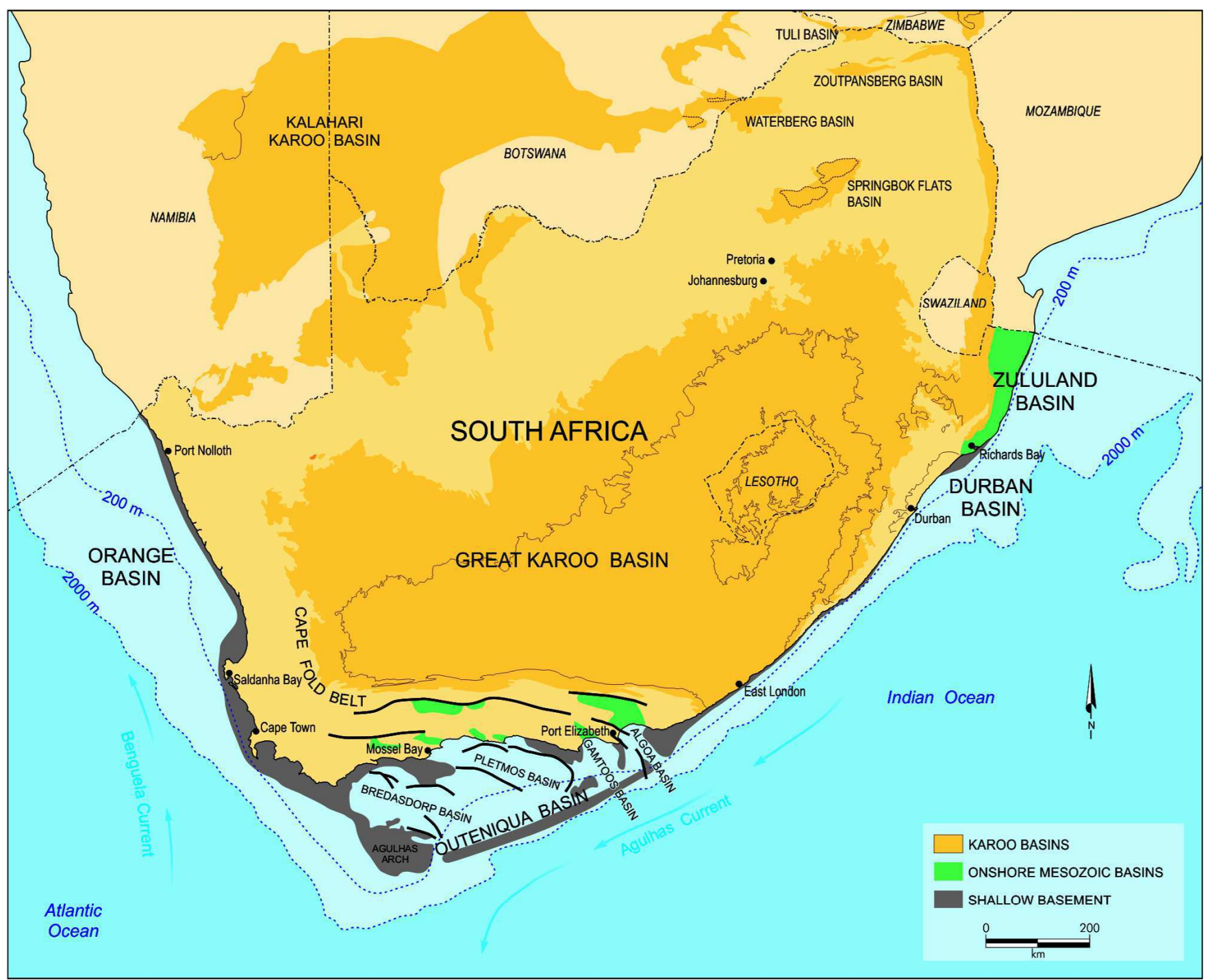

Figure 11. Map of Southern Africa showing the location of the main sedimentary basins. From Petroleum Agency SA, (2014). 
Johnson et al., 2006). More recently, observation of southward dipping décollements and other features have brought this interpretation into question (Lindeque et al., 2009). The smaller northern Karoo basins in Zambia, Zimbabwe, Tanzania and Malalwi are mainly fault controlled. The sediments of the Karoo basin include the glacial deposits of the Dwyka Group at the base of the succession, inland sea and lacustrine shales, turbidite complexes, deltaic sandstones and coals in the Ecca Group and later fluvial and aeolian deposits of the Beaufort Group. These sediments have undergone metamorphism, massive dolerite intrusion and major exhumation in places (Figure 12).

After earlier exploration for conventional hydrocarbons, the Karoo basins are now rather regarded as holding potential for unconventional resources. The northern outlying basins and northern part of the main basin have potential for coal bed methane and possibly minor conventional oil. Permian and Triassic coal seams in the Tuli,
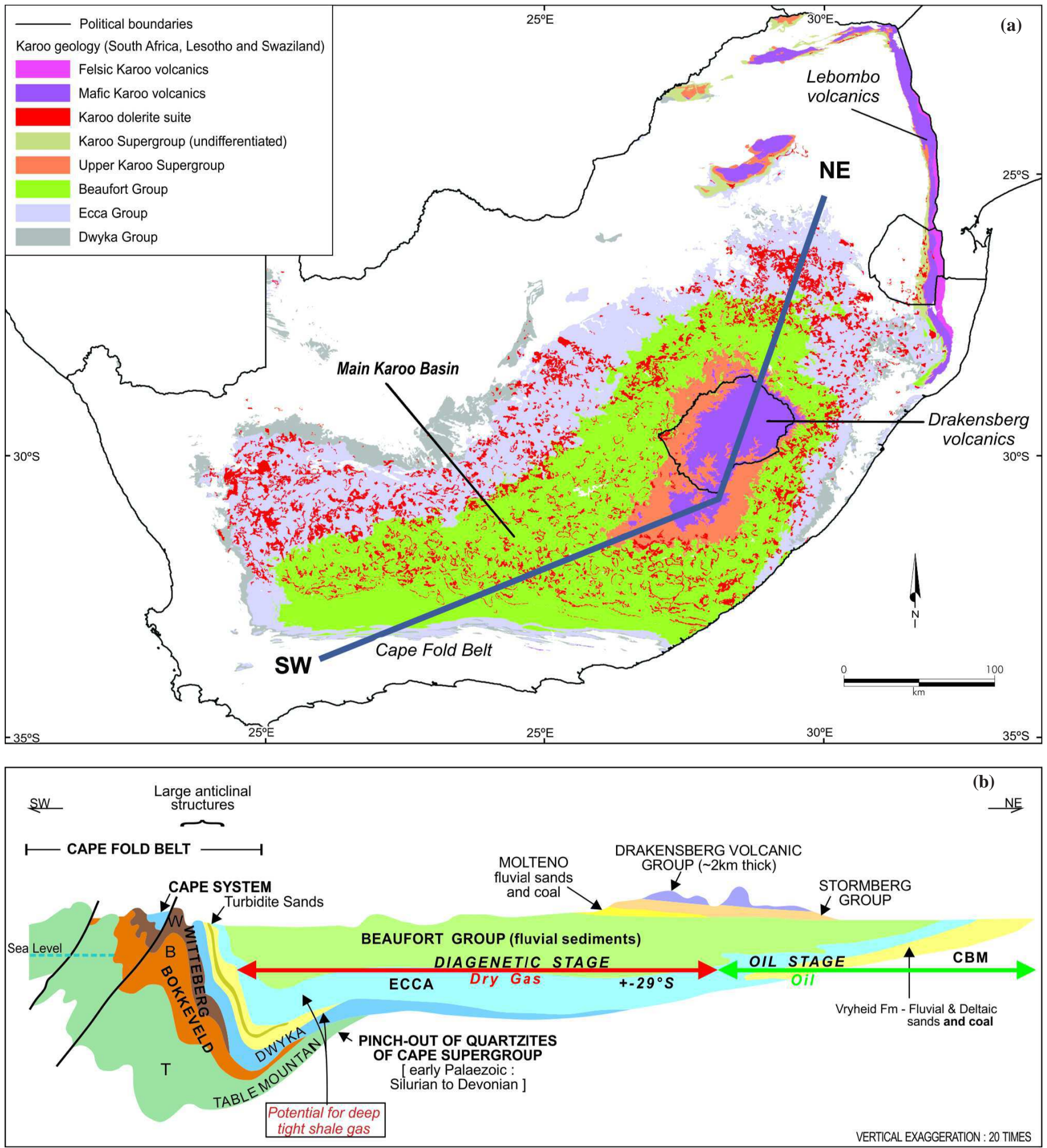

Figure 12. (a) Geological Map and (b) geological cross-section of the Karoo basin showing the main sedimentary formations and petroleum maturation zones. From Petroleum Agency SA, (2014). 
Lephalale, Tshipise and Springbok Flats Basins are all being explored for coal bed methane resources. The central part of the basin overlying the Witwatersrand Supergroup has demonstrated potential for microbially generated biogenic gas, discovered in what have become known as the Free State and Evander Gas Fields. The main basin is regarded as having world class potential for shale gas. The primary source rock is expected to be the Whitehill Formation within the Permian Lower-Ecca.

Jurassic uplift, rifting and volcanism across Antarctica, the Falklands and southern Africa, heralded the breakup of the Gondwana supercontinent (Watkeys, 2006). In the middle Jurassic, Antarctica and Madagascar moved away southwards from the African plate opening the Durban and Zululand basins off South Africa's east coast. Early Cretaceous movement of the Falkland Plateau and other micro-plates to the southwest controlled by the Aghulas-Falkland Fracture Zone, created the Outeniqua Basin's rift half-grabens off the south coast (Figure 13). These rifts form the basis of the Outeniqua's sub-basins, viz. the Algoa, Gamtoos, Pletmos, Bredasdorp and Southern Outeniqua basins (Broad et al., 2006).

Rifting off the south coast ended as the Falkland Plate cleared the African plate and the margin was transformed from a zone of dextral shearing to a true passive margin. The Orange Basin off the west coast was formed as the South American plate detached from Africa. The early north-south trending grabens and half-grabens are covered by later Cretaceous and Cenozoic passive margin sediments. While all the offshore basins demonstrate synrift and drift phases of sedimentation, the separation is less clear in the Outeniqua Basin due to the transform movement along the Aghulas-Falkland Fracture Zone (Broad et al., 2006).

The sediments encountered to date in South Africa's offshore Mesozoic basins are almost entirely clastic in origin. Generally, the earlier synrift successions in these basins represent lake and river deposits, with volcanics and volcaniclastics being common, especially along the western margin. The synrift successions are usually overlain by further continental deposits, or directly by deltaic and shallow marine sediments. The main drift successions are represented by thick deposits of marine sediments, ranging from shelf to deep marine in environment. Argillaceous successions are punctuated by basin floor fans and sandy turbidites successions founded by unconformities representing time breaks (Figure 14).

While all South Africa's offshore basins have shown some indication of working petroleum systems and the presence of both gas and oil during earlier exploration, the only production has been from the Bredasdorp sub-basin of the Outeniqua Basin off the south coast. Gas has been produced since the early 1990s from shallow marine Valanginian aged (circa 139 to $132 \mathrm{Ma}$ ) sandstones deposited on the flanks of the basin, while oil has been produced from Aptian and Albian aged (circa 125 to $100 \mathrm{Ma}$ ) basin floor fan systems in the centre of this same sub-basin. Substantial gas has been discovered off the west coast in Albian aged fluvial and shallow marine sandstones, while waxy oil has been discovered within the graben succession.

Exploration of the deep and ultra-deep waters off South Africa's coast is now underway and new exploration data is yielding new insights into the formation of and depositional environments of sediments within these basins.

\section{East Africa}

A series of rift-related basins occur along the coast of East Africa at the boundary of the African continental crust and the basaltic crust of the Indian Ocean. Basins also occur separated from Africa off the west coast of Madagascar and around the Seychelles (Figure 15). The general stratigraphic sequence begins with Carboniferous to

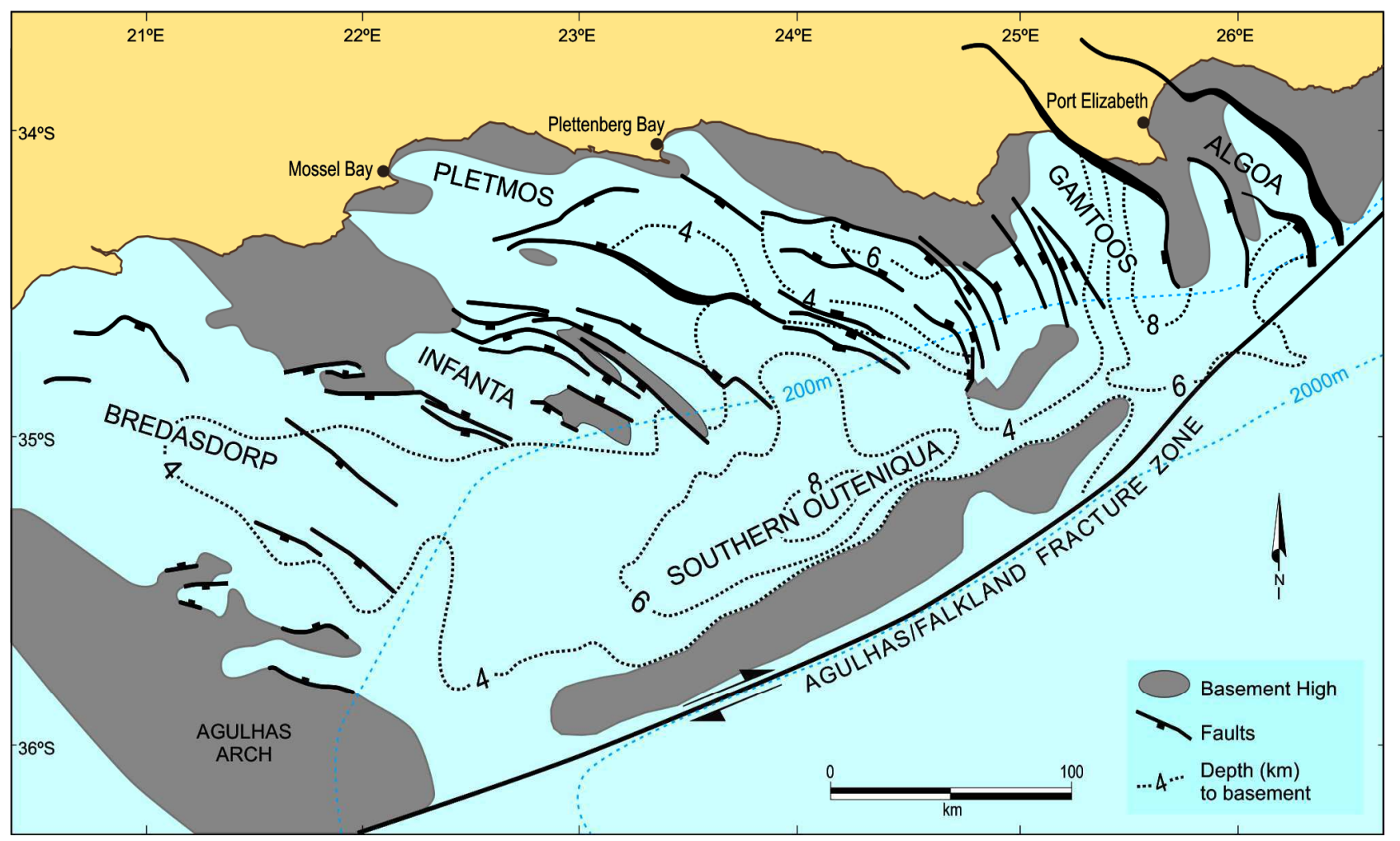

Figure 13. Map showing the distribution of the offshore basins of southern Africa. From Petroleum Agency SA, (2014). 
ORANGE BASIN

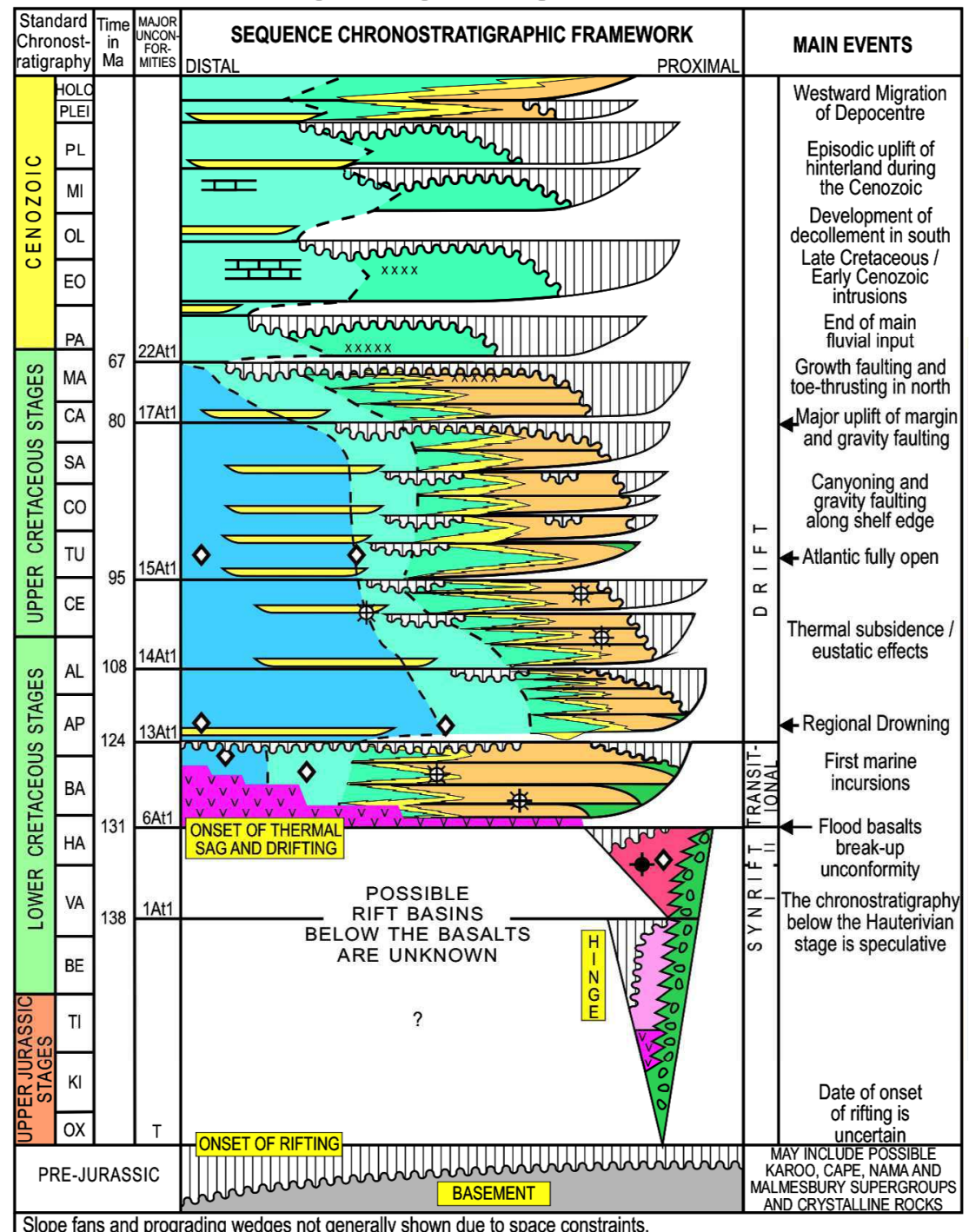

BREDASDORP SUB-BASIN

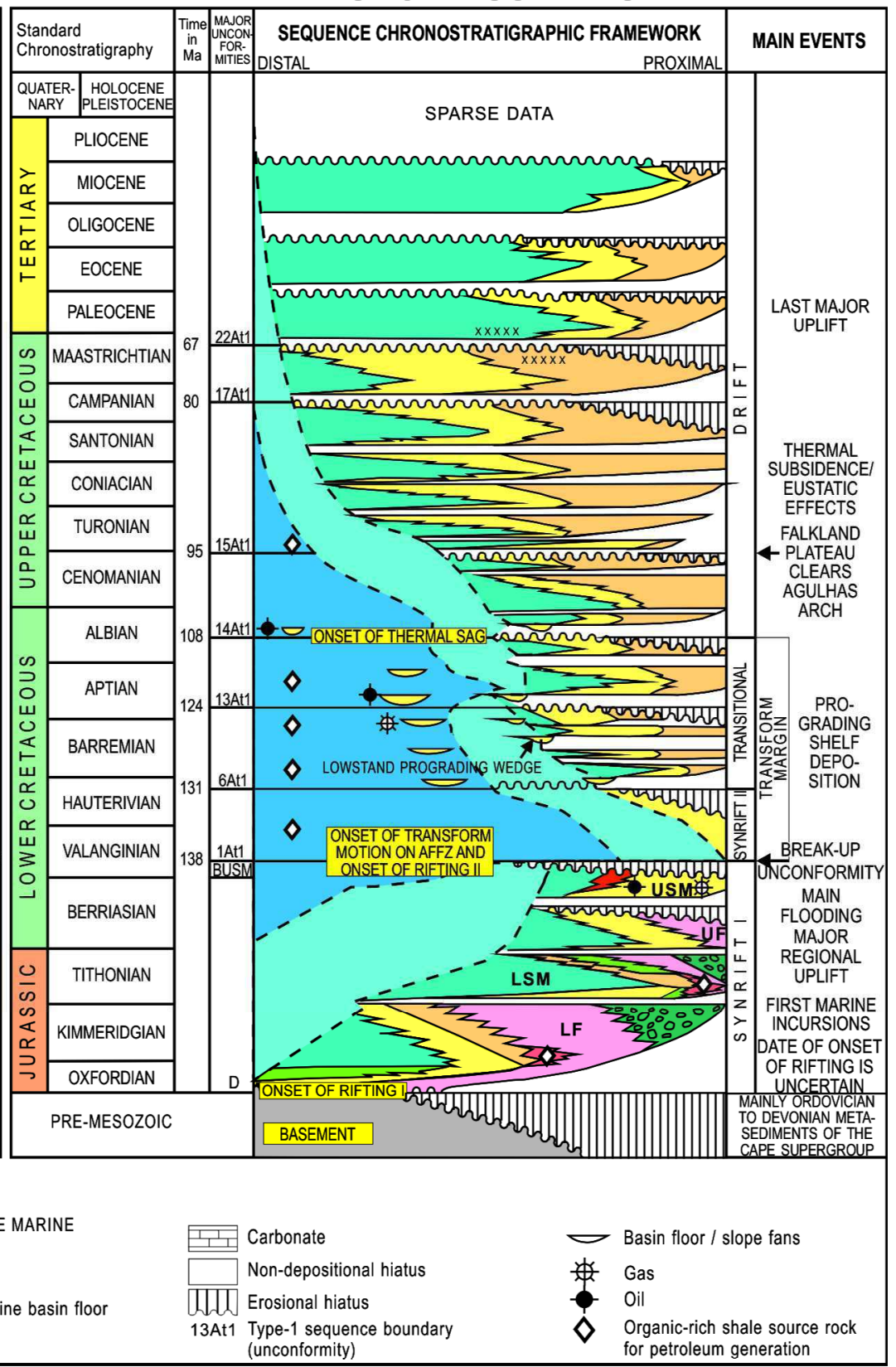
3At1 Type-1 sequence Organic-rich shale source
for petroleum generation
NON-MARINE
lope fans and prograding wedges not generally shown due to space constraints.

NON-MARINE
\begin{tabular}{|l|l}
\hline$x \times x$ & Igneous intrusions \\
\hline $00^{0}$ & Alluvial \\
\hline 7 & Fluvial / Lacustrine \\
\hline & Evaporites \\
\hline$v^{\vee} v^{v}$ & Volcanics \\
\hline
\end{tabular}

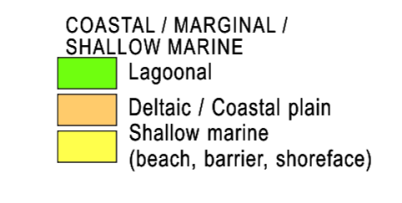

Figure 14. Stratigraphic columns of the Orange River and Bredasdorp sub-basins of offshore Southern Africa showing the distribution of unconformities, source rocks and reservoirs. From Petroleum Agency SA, (2014). 


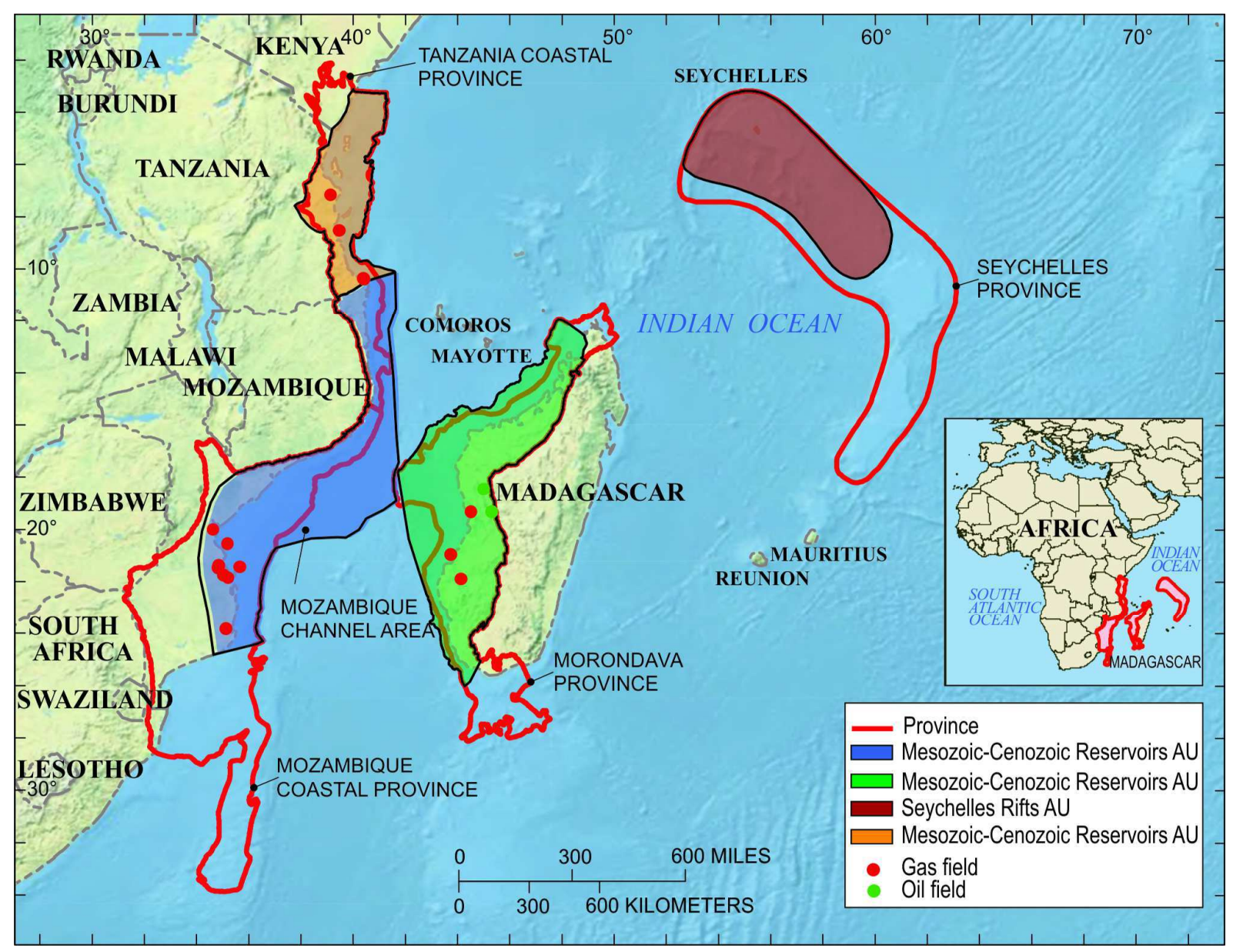

Figure 15. Map of the East African coastal basins. From Brownfield, (2012).

Triassic syn-rift continental clastics, possibly of Karoo age, followed by Jurassic to Recent marine muds, sands and carbonates, with occasional igneous volcanic rocks. Source rock intervals occur throughout the Permian, Triassic and Early Mid-Jurassic intervals. Potential reservoirs occur in Palaeozoic - Jurassic sands (Figure 16). Significant gas discoveries have been made offshore of Mozambique and Tanzania, notably in Lower Cretaceous sands at Songo Songo and in Miocene sands at Mnazi Bay. Despite the occurrence of oil seeps along the coast, commercial oil has yet to be found (PereiraRego et al., 2013). The Lamu embayment of Kenya has attracted exploration interest (Nyaberi and Rop, 2013). Gas has been discovered in Tertiary turbidites. The recent Subird-1 oil discovery confirms the potential of the continental margin.

\section{The Nile Delta}

Commencing in the Jurassic Period carbonate and clastic shelf edge sediments were deposited along the northern edge of the African shield. Subsidence and sedimentation of the palaeo-Nile began in the Early Oligocene (Figures 17 and 18). On several occasions, notably at the end of the Cretaceous and Eocene periods, steeply incised channels were cut across the shelf edge sediments. This channelling culminated when the Mediterranean dried out during the Messinian salinity crisis (c. 5.9-5.3 MY). As sea level rose, the channels were variously infilled with sand and shale that provide a range of stratigraphic and combination traps sealed beneath a widespread
Pliocene shale unit. Source rocks range in age from the Cretaceous to early Miocene periods (Dolson et al., 2005), and have generated substantial quantities of oil and gas, much of which is biogenic. There is also potential for tight gas production from extremely deeply buried infra-Cambrian source rocks (Craig et al., 2005).

\section{Conclusions}

Space only allows a brief review of the petroleum geology of Africa, so conclusions must inevitably be brief. Though today Africa only produces $7.7 \%$ of the world's oil, and $7.6 \%$ of the world's natural gas (Table 1), there is no doubt that petroleum production could dramatically accelerate without any further exploration. All that is needed is political stability and less corruption. Once these are achieved not only can existing reserves be exploited, but the identification of new resources will follow. Ever improving seismic and engineering technology will enable petroleum to be found and produced in ever deeper offshore areas. All of this will only happen if economic conditions are favourable. The oil price at the time of writing (December 2014) concentrates the petroleum industry's collective mind wonderfully. The factors that control the petroleum prospectivity of Africa are various, and include the stratigraphically wide range of source rocks that notably include Late Cretaceous shale buried beneath Tertiary clastic piles, the steady uplift of African cratons yielding a steady supply of sand, and the multiplicity of trap types, both structural and stratigraphic (Burke et al., 2003). 


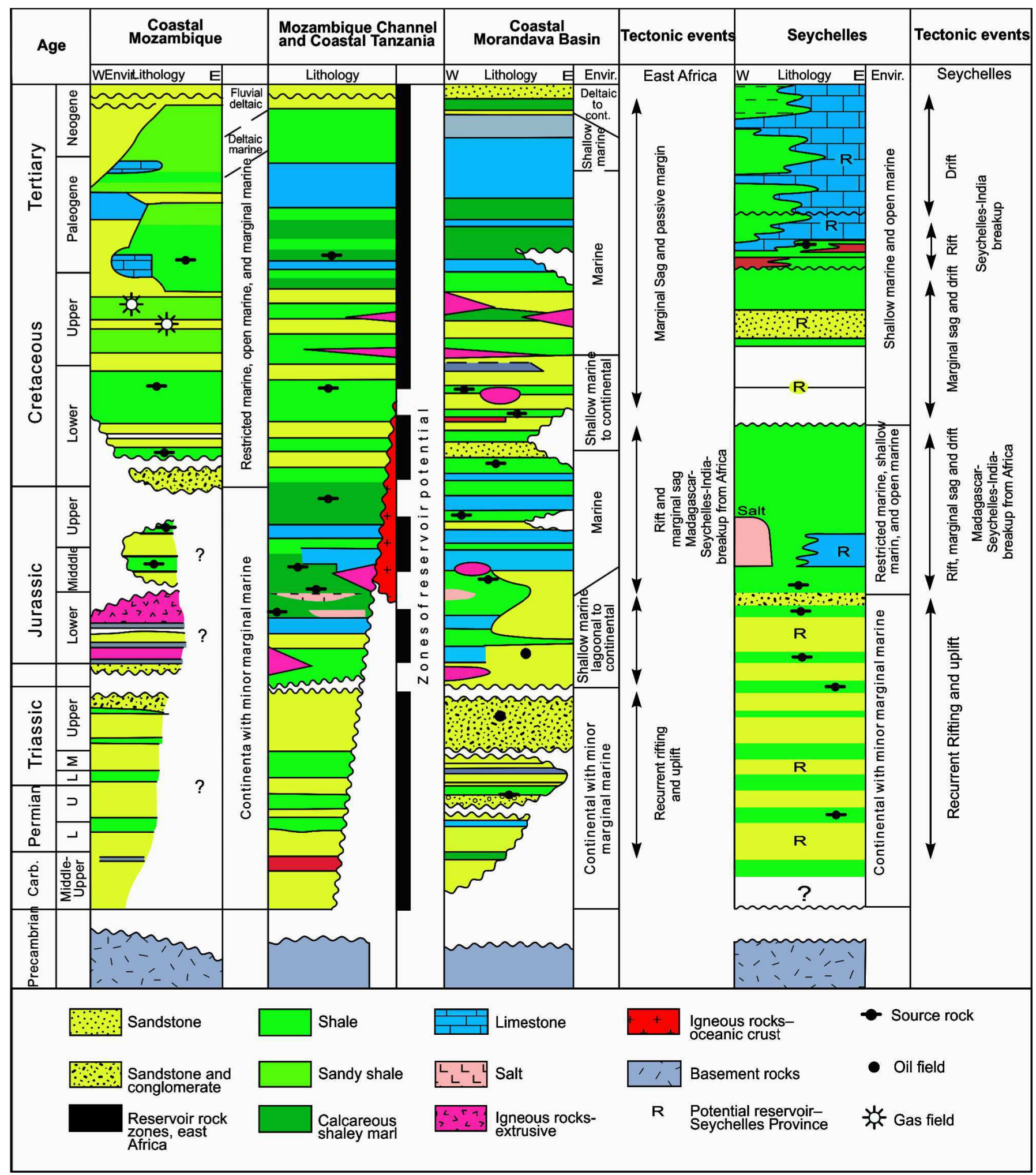

Figure 16. Summary stratigraphic columns of the East African coastal basins. From Kirschbaum, (2010).

Table 2 attempts to classify the various types of African petroliferous basins and their proven reserves.

This paper has only reviewed conventional petroleum. Unconventional petroleum, shale gas, shale oil and coal bed methane have great and as yet hardly explored potential (EIA/ARI 2013). The stratigraphically diverse organic-rich shales of North Africa have potential for shale gas and shale oil. As described above, the Karoo Basin has potential for coal bed methane and for shale gas. There are objections to shale gas production in desert and semi-desert areas due to the shortage of water. These objections need to be put into perspective. With proper treatment facilities, $80 \%$ of flow back water from hydraulic fracturing can be recycled and used in the next well. 


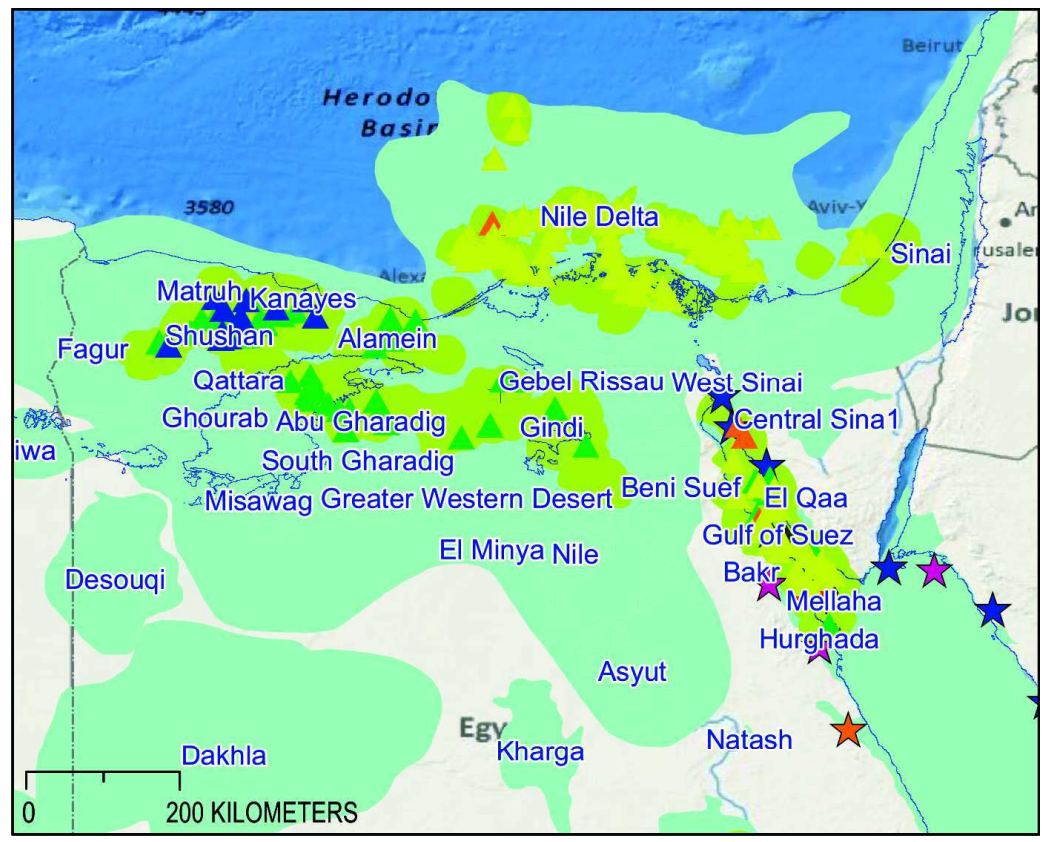

Figure 17. Map of the Nile delta and its offshore extension showing oil and gas fields. For key see Figure 2. Courtesy of the Exploration Framework of Africa Team $\odot$.

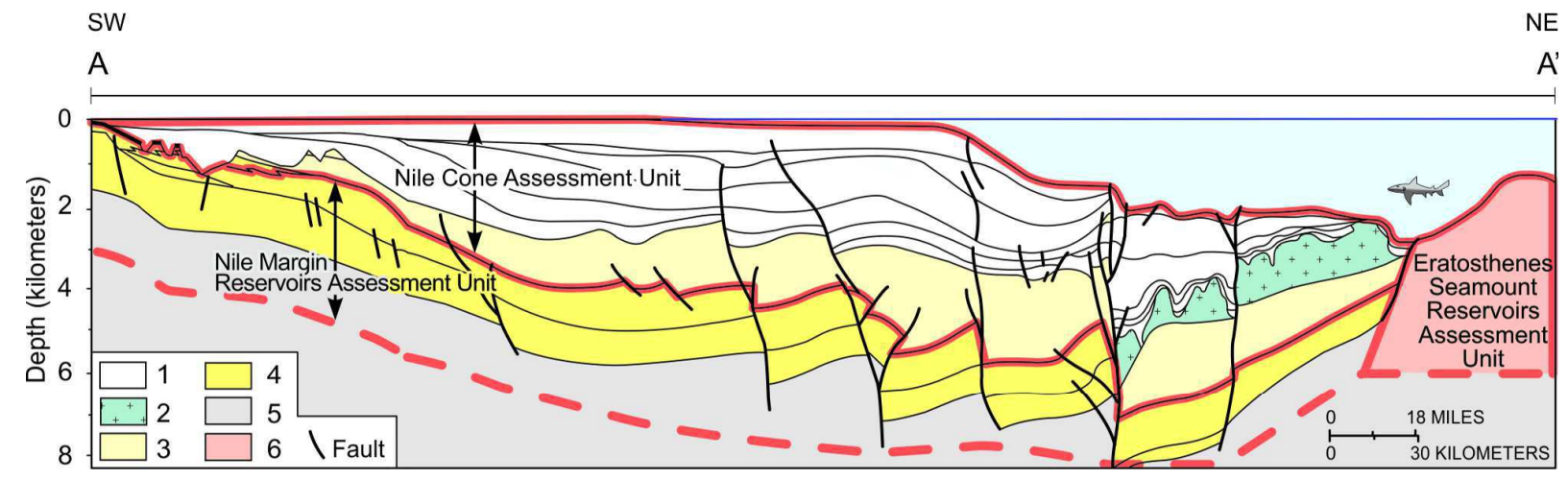

Figure 18. Cross-section of the Nile delta cone. Key: 1, Miocene (post-Messinian) and Pliocene-Quaternary; 2, Messinian Salt; 3, Miocene (pre-Messinian); 4, Palaeogene-Cretaceous; 5, hypothesized pre-Cretaceous; 6, Eratosthenes Seamount. From Kirschbaum, (2010).

Table 2. Classification of petroleum provinces of Africa by basin type. Production figures used are for 2013 (taken from the BP Statistical Review, 2014); only significant gas production is given. Courtesy of D. Clark-Lowes, Nubian Consulting.

\begin{tabular}{|l|l|l|l|}
\hline \multicolumn{1}{|c|}{ Basin type } & \multicolumn{1}{|c|}{ Petroleum Play Details } & \multicolumn{1}{c|}{$\begin{array}{c}\text { Gas production } \\
\text { (\% of Africa Total) }\end{array}$} & $\begin{array}{c}\text { Oil production } \\
\text { (\% of Africa Total)* }\end{array}$ \\
\hline Cratonic Basins & $\begin{array}{l}\text { Devonian/Silurian charge (N. Africa) } \\
\text { Permian charge (Karoo) } \\
\text { Mesozoic charge (Western Desert Egypt) }\end{array}$ & $\begin{array}{l}22 \% \\
\text { none/minimal } \\
4 \%\end{array}$ & $\begin{array}{l}41 \% \\
\text { none/minimal } \\
\text { none/minimal }\end{array}$ \\
\hline Cretaceous Rifts & Central/North Africa (incl. Sirte Basin) & $15 \%$ & $2 \%$ \\
\hline Neogene Rifts (East African Rift system) & East Africa & none/minimal & none/minimal \\
\hline Salt province of West African Margin & syn-rift (North of Niger Delta) & none/minimal & none/minimal \\
post-rift (South of Niger Delta) & $27 \%$ & $3 \%$ \\
\hline Continental margin provinces & South, East and North Africa & $5 \%$ & $18 \%$ \\
\hline Delta Regions & Niger Delta & $26 \%$ & $27 \%$ \\
\hline Other & Nile Delta & none/minimal & $9 \%$ \\
\hline $\begin{array}{l}\text { Totals (thousand barrels of oil per day } \\
\text { (bopd); billion cubic feet per day (bcf/d)) }\end{array}$ & & $1 \%$ & 19.80 \\
\hline
\end{tabular}

* figures given for Libya are from 2010, the last year before production was interrupted by the overthrow of Ghadafi 
Water usage per BTU (British Thermal Unit) for shale gas is the lowest for any source of energy, including 'green' energy sources (Sources: US Ground Water Protection Agency \& the US Department of Energy). In 2011 in the USA all the shale gas wells drilled and completed used $0.3 \%$ of US freshwater consumption (Golf courses used $0.5 \%$ ) Source: www.TheEnergyCollective.com. Much of the Texas Barnett shale gas production area lies in semi-desert. Water abstraction for hydraulic fracturing is a tiny percentage of the total amount of water abstracted for other industrial processes, domestic use, lawns and golf courses.

\section{Acknowledgements}

We are very grateful to Roger Bignell, David Boote, Danny ClarkLowes, Duncan Macgregor and Peter Wigley for offering constructive comments on the first draft of the manuscript. The end result has benefitted greatly from their many years of pan-African petroleum exploration experience. We are also extremely grateful to the Exploration Fabric of Africa Team for permission to use many illustrations from the Ed Purdy Memorial Project.

\section{References}

Broad, D.S., Jungslager, E.H.A., McLachlan, I.R. and Roux, J., (2006). Offshore Mesozoic Basins. In: Johnson, M.R, Anhaeusser, C.R. and Thomas, R.J. (eds.). The Geology of South Africa. Geological Society of South Africa. Geological Society of South Africa, Johannesburg and Council for Geoscience, Pretoria, 553571.

Brownfield, M.E., (2012). Assessment of Undiscovered Oil and Gas Resources of the Chad Basin Province, North-Central Africa. USGS World Petroleum Resources Project. 2pp.

Brownfield, M.E., (2013). Assessment of Undiscovered Oil and Gas Resources of Four East Africa Geologic Provinces. USGS World Petroleum Resources Assessment Project. 4pp.

Burke, K., MacGregor, D.S. and Cameron, N.R. (2003). Africa's petroleum systems: four tectonic 'Aces' in the past 600 million years. In: Petroleum Geology of Africa: New Themes \& Developing Technologies. Arthur, T.J., MacGregor, D.S. and Cameron, N.R. (eds.). Petroleum Geology of Africa, New themes and developing technologies. Geol Soc. London Spec. Publ. No. 207. 21-60.

Craig, J., Grigo, D., Rebora, A, Serafini, G. and Tebaldi, J. (2005). From Neoproterozoic to Early Cenozoic: exploring the potential of older and deeper hydrocarbon plays across North Africa and the Middle East. In: Vining, B.A. and Pickering. (Eds) Petroleum Geology: From Mature Basins to New Frontiers - Proceedings of the 6th Petroleum Geology Conference, DOI: 10.1144/ 0070673. The Geological Society, London. 673-705.

Dolson, J.C., Boucher, P.J., Siok, J. and Heppard, P.D. (2005). Key challenges to realizing full potential in an emerging giant gas province: Nile Delta/Mediterranean offshore, deep water, Egypt. In: Dore, A.G. and Vining, B.A. (eds.). Petroleum Geology: NorthWest Europe and Global Perspectives-Proceedings of the 6th Petroleum Geology Conference, Petroleum Geology Conferences Ltd. The Geological Society, London. 607-624.

Doughty, C., (1888). Travels in Arabia Deserta. 2 Vols. Cambridge University Press.

EIA/ARI, (2013). World shale gas and oil resource assessment. Chapters XIV-XIX. www.eia.gov/analysis/studies/worldshalegas/ pdf/chaptersxiv_xix.pdf. 104pp.

England, G.L., Rasmussen, B., Krapez, B. and Groves. D.I., (2002). Archaean oil migration in the Witwatersrand Basin of South
Africa. Jour. Geol Soc, London, Vol. 159, 2002, pp. 189-201.

Genik, G.J., (1993). Petroleum Geology of Cretaceous-Tertiary Rift Basins in Niger, Chad. Amer. Assoc. Petrol Geol. Bull, 77, 14051434.

Guiraud, R. and Bosworth, W., (1997). Senonian basin inversion and rejuvenation of rifting in Africa and Arabia: synthesis and implications to plate-scale tectonics. Tectonophysics, 282, 3982.

Husseini, M.I., (1990). The Cambro-Ordovician of Arabia and adjacent plates: a glacio-eustatic model. Jour. Petrol. Geol. 13.26788.

Johnson, M.R., van Vuuren, C.J., Visser, J.N.J., Cole, D.I., Wickens, H. de V., Christie, A.D.M., Roberts, D.L. and Brandl, G., (2006). Sedimentary rocks of the Karoo Group. In: Johnson, M.R, Anhaeusser, C.R. and Thomas, R.J (eds.). The Geology of South Africa. Geological Society of South Africa, Johannesburg and Council for Geoscience, Pretoria, 461-499.

Kirschbaum, M.E., (2010). Assessment of Undiscovered Oil and Gas Resources of the Nile Delta Basin Province, Eastern Mediterranean. USGS World Petroleum Resources Project 4pp.

Lindeque, A., de Wit, M.J., Ryberg, T., Weber, M. and Chevalier, L., (2011). Deep crustal profile across the southern Karoo Basin and Beattie Magnetic Anomaly, South Africa: An integrated interpretation with tectonic implications. South African Journal of Geology, Special Inkaba ye Afrika II volume 114 (3-4), 265292.

Lirond, D., Dingsheng, C., Zhi, L., Zhiwie, Z. and Jingchun, W., (2013). Petroleum Geology of the Fula Sub-basin, Muglad, Sudan. Jour. Pet. Geol. 36.1. 43-59.

Morgan, R., (2003). Prospectivity of ultradeep water: the case for petroleum generation and migration within the outer parts of the Niger Delta. In: Arthur, T.J., MacGregor, D.S. and Cameron, N.R. (eds.). Petroleum Geology of Africa. New Themes and Developing Technologies. Geol. Soc. Sp. Pub. 207. 151-164.

Nyaberi, M.D. and Rop, B.K., (2013). Petroleum prospects of Lamu Basin, South-Eastern Kenya. Journal of the Geological Society of India, 83, 414-422.

Pereira-Rego, M.C., Carr, A.D. and Cameron, N.R. (2013). Posted April Gas Success along the Margin of East Africa, But Where Is All the Generated Oil? Search and Discovery Article No. 10488. Amer. Assoc. Petrol. Geol. 35pp.

Petroleum Agency SA, (2014). Petroleum Exploration in South Africa. Information and Opportunities. Petroleum Agency SA. Cape Town. 1-44.

Purdy, E.G. and MacGregor, D.S., (2003). Map compilations and synthesis of Africa's petroleum basins and systems. In: Arthur T. J., MacGregor, D.S. and Cameron, N.R. (eds.). Petroleum Geology of Africa: New Themes and Developing Technologies. Geological Society, London, Special Publications, 207, 1-8.

Schenk, C.J., Klett, T.R., Whidden, K.J., Kirschbaum, M.A., Charpentier, R.R., Cook, T.A., Brownfield, M.E., and Pitman, J.K., (2012). USGS Assessment of Undiscovered Conventional Oil and Gas Resources of North Africa, 2012. U.S. Geological Survey Fact Sheet 2012-3147, USGS, 4pp.

Selley, R.C., (1997a). African Basins (Ed.) Elsevier. Amsterdam. 393pp.

Selley, R.C., (1997b). The sedimentary basins of Northwest Africa: stratigraphy and sedimentation. In: African Basins. Selley, R.C. (ed.). Elsevier, Amsterdam. 3-16.

Watkeys, M.K., (2006). Gondwana Break-up: a South African Perspective. In: Johnson, M.R., Anhaeusser, C.R. and Thomas, R.J. (eds.). The Geology of South Africa. Geological Society of South Africa. Geological Society of South Africa, Johannesburg and Council for Geoscience, Pretoria, 531-539. 


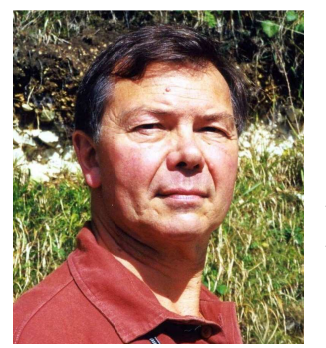

Richard Selley is Emeritus Professor of Petroleum Geology and a Senior Research Fellow at Imperial College, London. He has more than 50 years of experience in the practice, research and teaching of petroleum geoscience. This includes years of exploring for petroleum across Africa, as well as assignments in coal and gold exploration. He has written too many papers and books on petroleum geoscience. Over 30 years ago he identified the first shale gas resources outside the USA in the UK. His national and international awards include the Silver Medal of the Geological Society of London for excellence in petroleum geoscience.

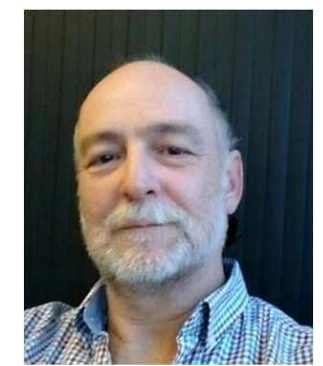

David van der Spuy started his career in 1987 as a geochemist with SOEKOR and has also worked for Halliburton, and as an independent consultant. Since late 1999, he has been with Petroleum Agency SA, where he has worked as a geochemist and general geologist, mostly on the geology of the Orange Basin. He now manages a team responsible for appraising South Africa's offshore resources and promoting South Africa's offshore potential to local and international oil and gas explorers. In 2014 he was awarded the PetroAfricanus award for excellence in Africa, in recognition of his efforts in attracting investment to South Africa. 